\title{
DESCRIPTION OF A NEW RACE OF THE FLORIDA WATER- RAT (NEOFIBER ALLENI)
}

\section{By Arthur H. Howell}

Attention has already been called by Bangs to the differences existing between typical Neofiber alleni of the east coast of Florida and the form inhabiting the fresh water lakes of the interior of the State. ${ }^{1}$ Acquisition of a considerable series of specimens from the shores of Lake Okeechobee confirms this opinion and shows the necessity for recognizing this form by name. It may be described as follows:

\section{Neofiber alleni nigrescens subsp. nov.}

\section{EVERGLADE WATER-RAT}

Type, No. 228,392, U. S. National Museum, Biological Survey collection; adult $\sigma^{\top}$, skin and skull; from Ritta, Florida (south shore Lake Okeechobee), March 2, 1918; collected by A. H. Howell; original number, 2269 .

Subspecific characters. - Similar to $N$. alleni alleni, but coloration more blackish (less brownish) above and more whitish (less buffy) below.

Color-General tone of upperparts fuscous-black, sometimes with a slight brownish tinge; sides paler, sometimes faintly washed with buffy wood brown; feet fuscous; tail fuscous-black; underparts grayish white, faintly washed with avellaneous, the chin with an irregular patch of fuscous or hair-brown. Young individuals are even darker than adults, being uniform chætura-black above.

Skull.-Not appreciably different from that of alleni.

Measurements.-Type: Total length, 328; tail vertebræ, 127; hind foot, 44. Skull: Basal length, 43.2: condylo-basal length, 44.8; zygomatic breadth, 27.4; length of nasals, 12; alveolar length of maxillary tooth row, 11.5.

Remarks.-This new race of the Florida water-rat or round-tailed muskrat is represented by a series of 25 specimens from southern Florida; nearly all are from the type locality-Ritta, on the south shore of Lake Okeechobee-but two are from Canal Point on the eastern shore, at the mouth of the West Palm Beach Canal, one from Zona on the North New River Canal, near Fort Lauderdale, and one from the head of Barnes River on the west coast near Chokoloskee. The species doubtless ranges locally throughout the Everglade region, south to Cape Sable, where, on a burnt marsh within half a mile of the coast I picked up several weathered skulls of the animal.

${ }^{1}$ Bangs, O., Proc. Boston Soc. Nat. Hist., Vol. 28, p. 183, 1898. 
The habits of this race are quite unlike those of typical alleni, as described by Chapman ${ }^{2}$ and Bangs. ${ }^{3}$ In the Okeechobee region the animals are found, not in ponds or marshes, but in dry or moist peat at a considerable distance from the lake shore. Before the lowering of the lake by drainage canals, however, the water must have extended close to the areas occupied by the rats and probably at times overflowed them.

I could get no positive evidence, however, that these rats ever built houses in the water, as alleni is known to do. Their burrows or tunnels were found in both neglected and cultivated fields, in cane patches, and even in dooryards and gardens. In the largest colony discovered, the tunnels ramified the friable peat soil in all directions, but apparently extended to no great depth; only small mounds of peat were found about the entrances. The rats were easily caught in unbaited steel traps or in Schuyler rat traps baited with banana.

In a small, brackish marsh at the head of Barnes River, about 8 miles east of Chokoloskee, I found a small colony of these water-rats and trapped a single specimen. This is the first record from the west coast of Florida, but residents stated that the animals are abundant in similar situations near the head of Turner's River and doubtless all the way down to the coast to Cape Sable. At this locality their tunnels were in wet muck in a part of the marsh containing a dense growth of switch grass with much of the old growth matted down on the ground. Good-sized piles of muck had been scratched out of some of the burrows and in a few cases the holes had been plugged with a round ball of soft muck. Deep trails led from one hole to another, but I could not find that any trails led to the pond a few yards away where cat-tail flags grew abundantly. Many pieces of flag stems, presumably cut by the rats, were floating on the water.

${ }^{2}$ Chapman, F. M., Bull. Am. Mus. Nat. Hist., II, pp. 119-122, 1889.

${ }^{3}$ Bangs, O., Proc. Boston Soc. Nat. Hist., Vol. 28, pp. 182-183, 1898. 


\section{$2 \mathrm{BHL}$ Biodiversity Heritage Library}

Howell, Arthur H. 1920. "Description of a New Race of the Florida Water-Rat (Neofiber alleni)." Journal of mammalogy 1, 79-80.

https://doi.org/10.2307/1373747.

View This Item Online: https://www.biodiversitylibrary.org/item/220052

DOI: https://doi.org/10.2307/1373747

Permalink: https://www.biodiversitylibrary.org/partpdf/90490

\section{Holding Institution}

Smithsonian Libraries

\section{Sponsored by}

Biodiversity Heritage Library

\section{Copyright \& Reuse}

Copyright Status: Not in copyright. The BHL knows of no copyright restrictions on this item.

This document was created from content at the Biodiversity Heritage Library, the world's largest open access digital library for biodiversity literature and archives. Visit BHL at https://www.biodiversitylibrary.org. 